\title{
U.S. International Transactions in 1996
}

Guy V.G. Stevens, of the Board's Division of International Finance, prepared this article. Virginia Carper provided research assistance.

After stabilizing in 1995, the U.S. current account deficit widened in 1996 to $\$ 165$ billion. The deficit increased sharply in the first three quarters of the year, but, because of strong export growth, narrowed significantly in the fourth quarter (chart 1). The widening of the deficit by $\$ 17$ billion was the net result of moderate-to-strong growth in all the key components of the current account: exports and imports of goods and services, income from U.S. and foreign portfolio and direct investments, and net unilateral transfers.

A $\$ 14$ billion increase in the deficit on traded goods and a smaller increase in the surplus on trade in services netted out to an overall increase in the deficit for trade in goods and services of $\$ 9$ billion (table 1). The value of exported goods grew at more than 6 percent; however, robust U.S. growth, a strengthening U.S. dollar, and a higher price for oil resulted in import growth that was equally strong in percentage terms but, because of the higher initial level of imports, higher in value terms. A similar arithmetic affected the change in the value of net services, but in the opposite direction. Service exports and imports grew at about the same 6 percent rate, but the higher initial value of service exports resulted in a $\$ 5$ billion increase in the net services balance.
1. U.S. external balances, 1985-96

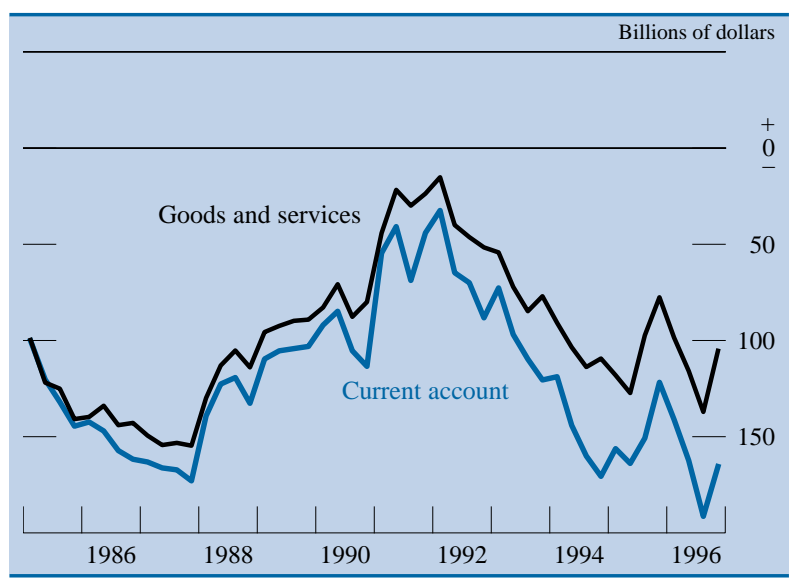

NoTE. The data are quarterly at seasonally adjusted annual rates. Current account data exclude foreign cash grants received in 1990-92.

SouRCE. U.S. Department of Commerce, Bureau of Economic Analysis, U.S. international transactions accounts.

Net investment income changed only marginally in 1996. The net change, again, was the outcome of a balancing of positive and negative effects, as a $\$ 7$ billion increase in net direct investment income nearly offset a growing net deficit for portfolio investment income. The former was attributable to the continued growth of, and remarkable profitability of, U.S. direct investment abroad, and the latter primarily to the large increase in net portfolio liabilities.

1. U.S. external balances, 1991-96

Billions of dollars

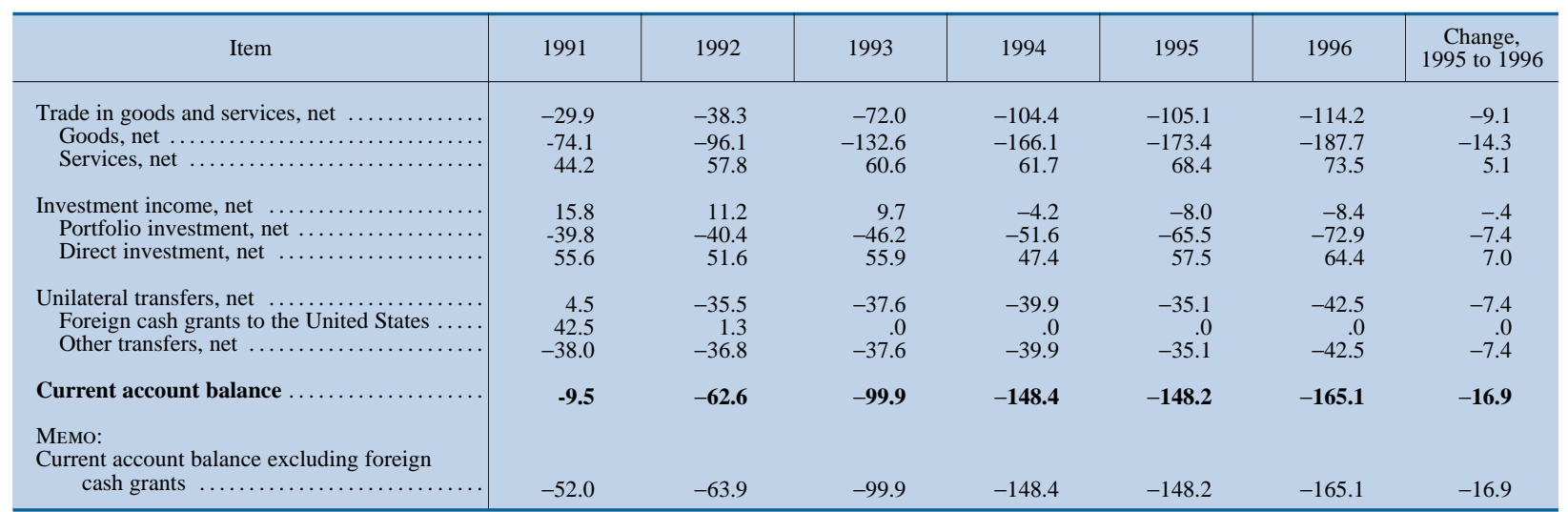

NotE. In this and the tables that follow, components may not sum to totals

SouRCE. U.S. Department of Commerce, Bureau of Economic Analysis, U.S. because of rounding. international transactions accounts. 
The change in the deficit on net unilateral transfers contributed about $\$ 7$ billion to the overall deficit on the current account. The large size of this increase should be a one-time occurrence; it was caused by delays in the disbursement of U.S. government grants, mainly because of the budget impasse at the end of 1995.

Recorded net capital inflows, both official and private, more than financed the $\$ 165$ billion current account deficit; as a result, the statistical discrepancy was negative for the first year since 1992. Of the capital inflows, about $\$ 123$ billion represented an increase in net foreign official holdings in the United States and $\$ 89$ billion an increase in net foreign private holdings.

\section{MAJOR ECONOMIC INFLUENCES ON U.S. INTERNATIONAL TRANSACTIONS}

The proximate determinants of the changes in the U.S. current account include economic growth in the United States and abroad, trends in U.S. international price competitiveness, movements in the U.S. international investment position, and changes in the rates of return on financial assets at home and abroad. The first two of these factors explain much of the deterioration of the trade balance in 1996 and earlier years, and the latter two explain the changes in portfolio and direct investment income.

\section{Relative Rates of Economic Growth}

In 1996 growth picked up significantly in both the United States and major foreign countries, with U.S. growth, at 2.4 percent year over year, about a percentage point below average foreign growth (table 2). Over the postwar period, in years when the U.S. economy and foreign economies have grown at approximately the same rate, U.S. imports have tended to increase significantly faster than U.S. exports. In fact, because the response of U.S. imports to changes in U.S. growth is considerably greater than the corresponding response of U.S. exports to changes in foreign growth, the U.S. trade balance has deteriorated even when foreign growth has been significantly stronger than that in the United States. This differential response, in conjunction with a starting point at which imports substantially exceed exports, is a major factor in explaining the change in the U.S. balance of trade in goods for 1996.

The overall foreign growth of 3.3 percent was an average of moderate growth in the industrial coun-
2. Growth of real GDP in the United States and selected foreign economies, 1994-96

Percentage change, year over year

\begin{tabular}{|c|c|c|c|}
\hline Country & 1994 & 1995 & $1996^{1}$ \\
\hline United States & 3.5 & 2.0 & 2.4 \\
\hline Total foreign & 4.4 & 2.5 & 3.3 \\
\hline Industrial countries $^{2}$ & 3.2 & 2.3 & 2.1 \\
\hline Canada ............ & 4.1 & 2.3 & 1.5 \\
\hline Western Europe & 3.0 & 2.5 & 1.9 \\
\hline Japan ............... & .7 & 1.3 & 3.7 \\
\hline Developing countries $^{3}$ & 6.6 & 3.0 & 5.7 \\
\hline Asia $\ldots \ldots \ldots \ldots \ldots$ & 8.2 & 7.8 & 6.6 \\
\hline Latin America .... & 4.4 & -3.8 & 4.4 \\
\hline Mexico $\ldots \ldots \ldots \ldots$ & 4.5 & -6.2 & 5.1 \\
\hline Other Latin America & 4.2 & 2.3 & 2.7 \\
\hline
\end{tabular}

Note. Aggregate measures are weighted by bilateral shares in U.S. nonagricultural merchandise exports in 1987-89.

1. Data for 1996 are partly estimated.

2. The industrial countries index includes Australia and New Zealand in addition to Canada, Japan, and Western Europe. The index for Western Europe comprises Belgium, France, Germany, Italy, the Netherlands, Sweden, Switzerland, the United Kingdom, Austria, Denmark, Finland, Greece, Ireland, Norway, Portugal, Spain, and Turkey.

3. The developing countries in the index for Asia are the Peoples Republic of China, Hong Kong, Korea, Malaysia, the Philippines, Singapore, and Taiwan. The countries in "Other Latin America" are Argentina, Brazil, Chile, and Venezuela.

SOURCE. Various national sources.

tries and a strong expansion in the developing countries. Growth in the developing countries of Asia continued at almost the strong 1995 pace. In Latin America, Mexico and Argentina rebounded from negative growth in 1995 to register year-over-year rates of 5.1 percent and 4.4 percent respectively.

\section{U.S. Price Competitiveness}

Broad measures of U.S. price competitiveness, such as the CPI-adjusted foreign exchange value of the dollar, have shown a moderate lessening of U.S. competitiveness since the middle of 1995 (chart 2). This real foreign exchange value of the dollar, in terms of the currencies of eighteen of our major trading partners, is computed as the ratio of U.S. consumer prices to foreign consumer prices translated into dollars at current nominal exchange rates. The rise in this measure over the past one and onehalf years is primarily the result of the appreciation of the dollar relative to the currencies of our major trading partners. The movements of direct measures of relative export and import prices confirm this moderate loss of U.S. price competitiveness (chart 3). U.S. exports lost some of their competitiveness visà-vis foreign goods; similarly, imports into the United States became somewhat more competitive with respect to U.S. domestic goods, primarily because of the continued appreciation of the U.S. dollar. 
2. CPI-adjusted foreign exchange value of the U.S. dollar, 1974-96

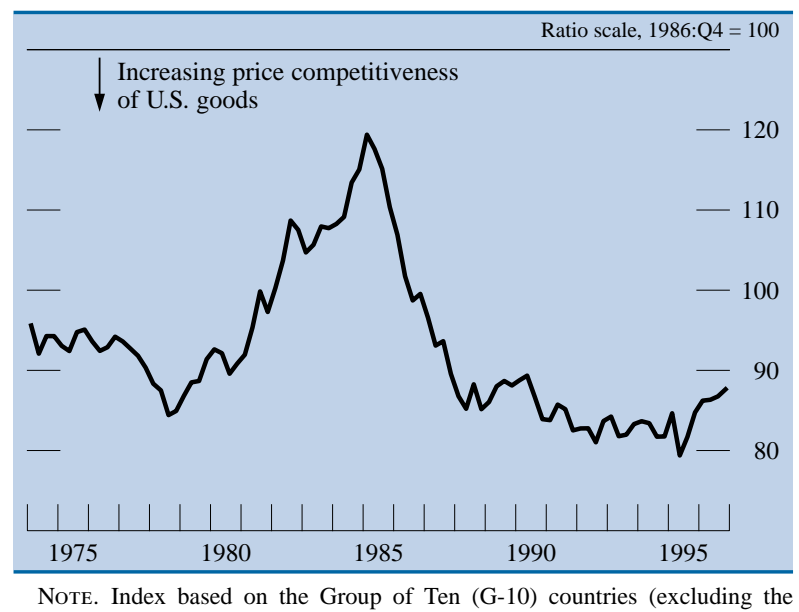
NotE. Index based on the Group of Ten (G-10) countries (exclud
United States) and eight developing countries. The data are quarterly.

Because of lags in the impact of the rise of the dollar on the trade balance, the effects of this reduced competitiveness are likely to continue into 1997 . In fact, the net effect of exchange rate changes on the trade balance in 1996 was probably positive, as the lagged effects of the dollar depreciation in early 1995 dominated those of the more recent dollar appreciation.

\section{The U.S. Net Investment Position and Differential Rates of Return on U.S. Claims and Liabilities}

Because of the run of current account deficits going back to the early 1980s, U.S. liabilities to foreigners-portfolio and direct-have grown much more rapidly than our claims on foreigners. Net liabilities grew by the end of 1996 to a total of approximately $\$ 1$ trillion (chart 4). This negative overall net investment position is a major factor explaining why net investment income is now negative.

The relatively small deficit on net investment income of $\$ 8.4$ billion in 1996, an amount little changed from 1995, illustrates the important influence of different rates of return on U.S. claims and liabilities. If the rate of return on all U.S. claims and liabilities had been the same in 1996, net investment income would have been equal to that common rate of return times the net investment position; for a 5 percent rate of return, about the 1996 average for portfolio claims and liabilities, net investment income would have been approximately negative $\$ 50$ billion,
3. Relative prices of exports and imports, 1988-96

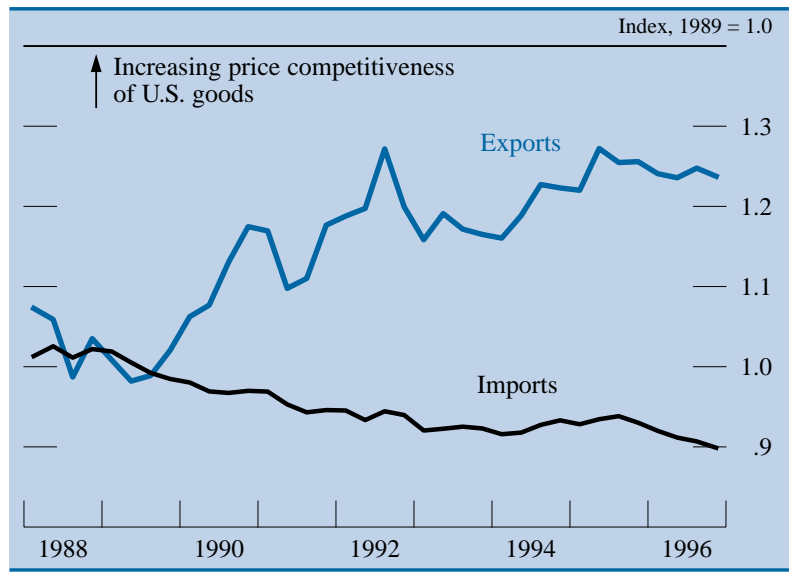

NoTE. For exports, the index is the ratio of foreign prices to U.S. export prices of nonagricultural products, excluding computers. For imports, the index is the ratio of U.S. import prices of non-oil imports, excluding computers, to the U.S. GDP deflator. The data are quarterly.

rather than the actual negative $\$ 8.4$ billion. The primary reason for the smaller size of the actual deficit is the consistently high rate of return on U.S. direct investment assets abroad, which, at almost 11 percent in 1996, was double the rates of return on nonresident holdings of portfolio and direct investment assets in the United States.

Changes in rates of return from 1995 to 1996, particularly the fall in the rates of return on portfolio liabilities and foreign direct investment in the United States, explain why net investment income changed so little in 1996 even as net liabilities increased substantially. Despite the fact that variations in rates of return on the various claims and liabilities had a

4. Net investment position, 1972-96

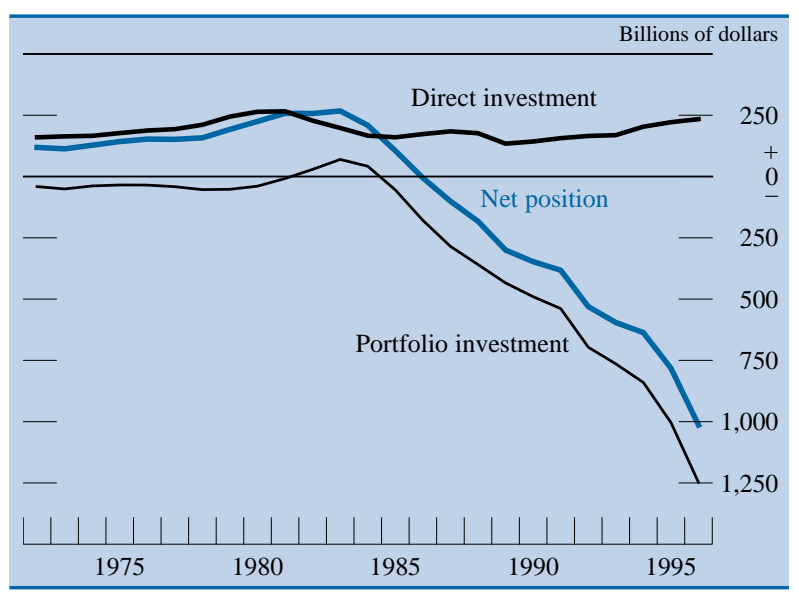

NotE. For 1972-95, the data are end-of-year totals for net direct investment, net portfolio investment, and their difference (shown as the "net position"). The year-end position for 1996 was constructed by adding the recorded investment flows during 1996 to the recorded year-end position for 1995 .

Source. U. S. Department of Commerce, Bureau of Economic Analysis. 
large positive effect on net investment income in 1996, the large and increasingly negative net investment position predisposes the United States to increasing deficits in the future.

\section{DEVELOPMENTS IN TRADE IN GOODS AND SERVICES}

The values of exports and imports of goods grew between 6 percent and 7 percent in 1996, down from the double-digit growth rates of 1995 (table 3). The deficit on traded goods increased $\$ 14$ billion, however, because the value of imports grew faster from a larger initial level (table 1). Service exports grew somewhat faster than imports, again from a higher base, leading to a $\$ 5$ billion increase in the surplus for net services.

\section{Exports}

The value of exports of goods and services, at $\$ 836$ billion for 1996 , rose slightly more than 6 percent for the year-less than half the strong rate of almost 13 percent in 1995 (table 3). Although the export value of goods and of services advanced at nearly the same rate, because of the relative size of these two categories, the change in the value of exported goods accounted for three-fourths of the total change. The categories of exports showing the sharpest increases in value were agricultural products, capital goods, and consumer goods.

Shipments of aircraft and parts led the increase in the value of exported capital goods, with a jump of more than 18 percent. After a period of sluggish sales, deliveries of large jet aircraft rebounded, especially toward the end of the year, as a result of robust growth in world air traffic, high airline profits, and projections of strong replacement demands. Because of the backlog of existing orders from foreign airlines, this strength in aircraft exports is expected to continue throughout 1997.

Exports of machinery also expanded vigorously in 1996, in response to strengthening investment expenditures abroad. Relatively large increases were registered in a wide range of categories, notably computers (including peripherals and parts), scientific and medical equipment, and various types of powergenerating equipment. The growth of machinery exports moderated a bit in response to a slowing in shipments of semiconductors and telecommunications equipment during the first part of the year; however, sales turned up toward the end of the year, and small annual increases were recorded in both

3. U.S. international trade in goods and services, 1994-96 Billions of dollars

\begin{tabular}{|c|c|c|c|c|c|}
\hline \multirow{2}{*}{ Item } & \multirow{2}{*}{1994} & \multirow{2}{*}{1995} & \multirow{2}{*}{1996} & \multicolumn{2}{|c|}{ Percentage change } \\
\hline & & & & 1994 to 1995 & 1995 to 1996 \\
\hline Balance on goods and services .. & -104 & -105 & -114 & $\cdots$ & . \\
\hline Exports of goods and services & 698 & 787 & 836 & 12.6 & 6.2 \\
\hline Services .................. & 196 & 211 & 224 & 7.5 & 6.3 \\
\hline Goods ................. & 502 & 576 & 612 & 14.6 & 6.2 \\
\hline Agricultural products & 47 & 57 & 61 & 21.6 & 7.4 \\
\hline Nonagricultural goods & 455 & 519 & 550 & 13.9 & 6.1 \\
\hline Capital goods ...... & 205 & 234 & 253 & 13.9 & 8.2 \\
\hline Aircraft and parts . . . . . . . . . & 31 & 26 & 31 & -17.0 & 18.1 \\
\hline Computers, peripherals, and parts . & 33 & 40 & 44 & 19.0 & 10.2 \\
\hline Semiconductors $\ldots \ldots \ldots \ldots \ldots$ & 25 & 34 & 36 & 35.6 & 4.5 \\
\hline Other capital goods . & 115 & 134 & 143 & 16.1 & 6.6 \\
\hline Consumer goods ....... & 60 & 64 & 70 & 7.4 & $\begin{array}{l}8.0 \\
8.9\end{array}$ \\
\hline Automotive products & 58 & 62 & 64 & 7.0 & 4.3 \\
\hline Industrial supplies $\ldots$ & 113 & 135 & 138 & 20.4 & 1.6 \\
\hline Other exports ....... & 20 & 23 & 25 & 17.0 & 7.9 \\
\hline Imports of goods and services & 803 & 892 & 950 & 11.1 & 6.5 \\
\hline Services .................. & 134 & 142 & 150 & 6.1 & 5.8 \\
\hline Goods $\ldots \ldots \ldots \ldots \ldots$ & 669 & 749 & 799 & 12.1 & 6.7 \\
\hline Petroleum and products & 51 & 55 & 68 & 7.4 & 24.0 \\
\hline Nonpetroleum goods ... & 617 & 694 & 731 & 12.5 & 5.3 \\
\hline Capital goods ....... & 184 & 221 & 229 & 20.1 & 3.4 \\
\hline 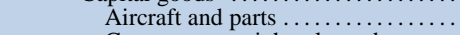 & 11 & 11 & 13 & -5.2 & 17.9 \\
\hline Computers, peripherals, and parts & 46 & 56 & 62 & 21.9 & 9.3 \\
\hline Semiconductors ................ & 26 & 39 & 37 & 49.3 & -6.0 \\
\hline Other capital goods & 101 & 115 & 118 & 14.5 & 2.3 \\
\hline Consumer goods ...... & 146 & 160 & 171 & 9.3 & 6.9 \\
\hline Automotive products & 118 & 125 & 130 & 5.5 & 4.3 \\
\hline Industrial supplies $\ldots \ldots \ldots$. & 114 & 129 & 136 & 13.3 & 5.7 \\
\hline Foods and other exports .... & 55 & 59 & 65 & 8.4 & 9.2 \\
\hline
\end{tabular}


categories. An important element in the expansion of these high tech categories is the rapid penetration of personal computers (PCs) into emerging markets (especially in Asia), indications of the beginning of a computer upgrade cycle by corporations, and the increasing role PCs play in communications.

The value of consumer goods exports grew 9 percent in 1996, a somewhat faster pace than in 1995. About 30 percent of the increase went to Mexico, 40 percent went to major industrial countries, and the remaining 30 percent went largely to Korea, China, Eastern Europe, and other countries in Latin America.

The increase in the value of agricultural exports was due entirely to price increases; the quantity of shipments declined, on balance, below the levels of 1995. Real exports fell sharply in the first three quarters of 1996, after disappointing U.S. harvests of corn and soybeans in the fall of 1995 and of wheat in the spring of 1996. These production shortfalls also pushed inventories of grain and oilseed to historic lows. As inventories were drawn down to critically low levels, prices of many agricultural exports rose to record highs. However, following the improved U.S. harvests in the fall of 1996, exports of agricultural products recovered strongly and prices fell substantially.

By area, nearly one-third of the increase in the value of merchandise exports in 1996 went to Mexico. Spurred by the restoration of robust economic growth, shipments to Mexico jumped more than 23 percent (table 4), with the sharpest increases in automotive products and consumer goods. Smaller increases went to Canada, Japan, Asia, and other countries in Latin America. Weak GDP growth in Western Europe held down the expansion of U.S. exports to that area.

4. U.S. exports of goods to its major trading partners, 1994-96

Billions of dollars

\begin{tabular}{|c|c|c|c|c|}
\hline Importing region & 1994 & 1995 & 1996 & $\begin{array}{c}\text { Percentage } \\
\text { change, } \\
1995 \text { to } 1996\end{array}$ \\
\hline Total & 503 & 576 & 612 & 6.2 \\
\hline Industrial countries ${ }^{1}$ & 293 & 335 & 351 & 4.6 \\
\hline Canada .......... & 115 & 128 & 134 & 5.0 \\
\hline Western Europe . & 115 & 132 & 137 & 3.6 \\
\hline Japan ............ & 52 & 63 & 66 & 4.5 \\
\hline Developing countries $^{2}$ & 209 & 241 & 261 & 8.5 \\
\hline Asia $\ldots \ldots \ldots \ldots \ldots$ & 104 & 131 & 135 & 3.8 \\
\hline Latin America ... & 92 & 96 & 109 & 13.9 \\
\hline Mexico $\ldots \ldots \ldots \ldots$ & 51 & 46 & 57 & 23.4 \\
\hline Other Latin America & 41 & 50 & 52 & 4.8 \\
\hline
\end{tabular}

1. See note 2 to table 2 .

2. See note 3 to table 2 .

SourCE. U.S. Department of Commerce, Bureau of Economic Analysis, U.S. international transactions accounts.
In terms of quantity, exports of goods and services grew 61/2 percent in 1996 (table 5). Service exports, however, expanded more slowly than goods exports. With only small increases in receipts from royalties and license fees and little change in the value of military sales, total service receipts increased about $3 \frac{1}{2}$ percent in real terms in 1996. The drop in agricultural exports and the marked slowdown in exports of semiconductors held down overall growth in the quantity of merchandise exports. Real merchandise exports, exclusive of agricultural products, semiconductors, and computers, grew 6 percent in 1996-the same rate as in 1995. Overall, exports of goods and services contributed 0.7 percentage point to U.S. real GDP growth in 1996 (year over year).

\section{Imports}

In 1996 total imports of goods and services rose in value at about the same rate as exports-little more than half the rate of growth in 1995 (table 3). The value of imported services and of imported goods increased at about the same rate. Varying stories for different import categories combined to produce this outcome.

\section{Oil Imports}

Although the volume of oil imports increased only $1 / 2$ percent from 1995 to 1996 , the value of oil imports rose 24 percent because of a 23 percent increase in the average price of imported oil. Several factors contributed to what appears to have been a temporary, though large, increase. At the time of this writing, prices have dropped back sharply from the levels prevailing at the end of 1996.

5. Change in the quantity of U.S. exports, 1994-96 Percentage change, year over year

\begin{tabular}{|c|c|c|c|}
\hline Type of export & 1994 & 1995 & 1996 \\
\hline All exports & 8.2 & 8.9 & 6.5 \\
\hline Services & 3.7 & 4.7 & 3.7 \\
\hline Goods $\ldots \ldots \ldots \ldots \ldots$ & 10.1 & 10.6 & 7.6 \\
\hline Agricultural products . & 3.4 & 11.7 & -2.2 \\
\hline Nonagricultural goods $\ldots \ldots \ldots \ldots$ & 10.8 & 10.5 & 8.7 \\
\hline Computers, peripherals, and parts & 26.9 & 41.0 & 43.8 \\
\hline Semiconductors $\ldots \ldots \ldots \ldots \ldots$ & 61.2 & 43.1 & 7.5 \\
\hline Other $\ldots \ldots \ldots \ldots \ldots \ldots \ldots \ldots$ & 7.3 & 6.3 & 5.7 \\
\hline \multirow{2}{*}{$\begin{array}{l}\text { Meмo: } \\
\text { Contribution of exports to U.S. GDP } \\
\quad \text { growth (percentage points) } \ldots\end{array}$} & & & \\
\hline & .8 & 1.0 & .7 \\
\hline
\end{tabular}

Note. Quantities are measured in chained (1992) dollars.

SourCE. U.S. Department of Commerce, Bureau of the Census. 
5. Oil prices, $1984-96$

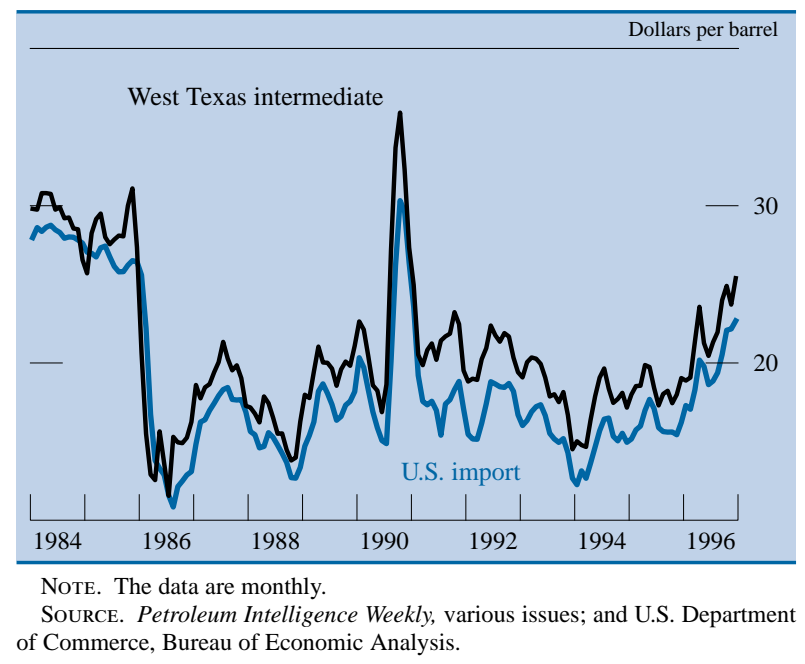

Changes in the prices of imported oil have tended to mirror changes in spot oil prices (West Texas intermediate) with a lag of several weeks (chart 5). Spot prices fell during the fourth quarter of 1995 but then rose at the beginning of 1996 to almost $\$ 19$ per barrel. This rise in price reflected increased demand for heating oil and depleted heating oil stocks as a result of a winter season that was much colder than usual throughout the Northern Hemisphere. At the same time, Iraq approached the United Nations with a plan to export a limited, although significant, amount of oil under U.N. supervision in return for permission to use the proceeds primarily for the purchase of humanitarian supplies. Refiners, uncertain about the availability of crude oil supplies from Iraq and concerned about the effect that such supplies might have on the price of oil, tended to keep their stocks low. With the oil industry operating at minimal, just-in-time inventory levels, oil prices reacted quite strongly to unanticipated shocks. Two such events, the delay in the startup of several North Sea fields and stronger-than-anticipated economic activity in the United States drove up oil prices during the second half of the year. Oil import prices mirrored the changes in spot prices and averaged $\$ 19.76$ per barrel in 1996, about $\$ 3.67$ above the average for 1995. Spot prices fell back during late January and February of this year when Iraqi oil was finally offered on the spot market and warmer-than-normal weather softened demand for home heating oil.

The quantity of oil imports rose from a rate of 8.8 million barrels per day in 1995 to 9.4 million barrels per day in 1996 (table 6). The higher level of imports more than accounted for an increase in U.S. consumption in the range of $1 / 2$ million barrels per day.

\section{Non-oil Imports}

The value of non-oil imports rose about $5 \frac{1}{2} 2$ percent in 1996 (table 3). Imports grew in response to the strength of U.S. economic activity and to the slight boost from the small increase in their price competitiveness; increases were recorded in almost all major import categories. One notable exception was imports of semiconductors. There was a large buildup in inventories in the semiconductor industry in 1995 and early 1996 that was drawn down beginning in early spring. After rising strongly during 1995, U.S. imports of semiconductors dropped during almost all of 1996 and turned up only at year-end. The deficit in the net semiconductor trade balance that had emerged in 1995 and continued into 1996 fell sharply during the year, as imports dropped and as exports turned up in the second half of the year.

In terms of quantity, imports of goods and services grew almost $6 \frac{1}{2}$ percent in 1996 , with imports of services expanding more slowly than goods (table 7). Overall, imports of goods and services subtracted 0.8 percentage point from U.S. real GDP growth in 1996 (year over year).

\section{Developments in Trade in Services}

Unlike the balance on trade in goods, in 1996 the balance on trade in services was positive and actually increased $\$ 5$ billion (table 8). The United States

6. U.S. oil consumption, production, and imports, selected years, 1980-96 Millions of barrels per day

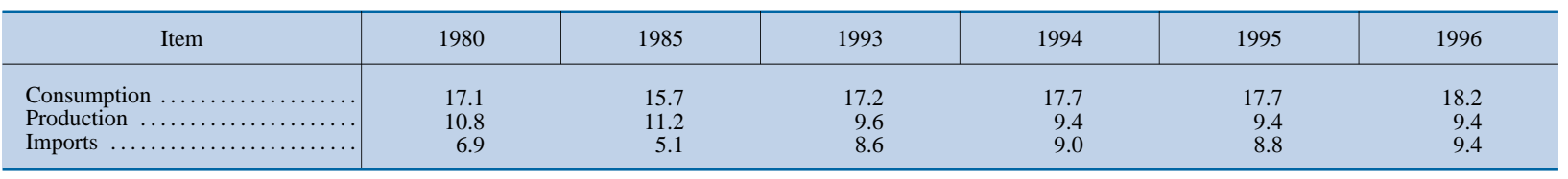

SoURCE. U.S. Department of Energy, Energy Information Administration. 
7. Change in the quantity of U.S. imports, 1994-96 Percentage change, year over year

\begin{tabular}{|c|c|c|c|}
\hline Type of import & 1994 & 1995 & 1996 \\
\hline All imports & 12.0 & 8.0 & 6.4 \\
\hline Services & 4.8 & 3.7 & 3.6 \\
\hline Goods $\ldots \ldots \ldots \ldots \ldots \ldots$ & 13.5 & 8.9 & 6.9 \\
\hline Petroleum and products .... & 62 & -1.7 & 5 \\
\hline Nonpetroleum goods $\ldots \ldots \ldots \ldots$ & $\begin{array}{r}0.2 \\
14.2\end{array}$ & $\begin{array}{r}-1.1 \\
9.8\end{array}$ & 7.4 \\
\hline Computers, peripherals, and parts & 36.3 & 38.8 & 33.8 \\
\hline Semiconductors ................ & 41.5 & 57.2 & 6.0 \\
\hline Other $\ldots \ldots \ldots \ldots \ldots \ldots \ldots \ldots$ & 11.5 & 5.4 & 5.1 \\
\hline \multirow{2}{*}{$\begin{array}{l}\text { MEMO: } \\
\text { Contribution of imports to U.S. GDP } \\
\quad \text { growth (percentage points) .... }\end{array}$} & & & \\
\hline & -1.4 & -1.0 & -.8 \\
\hline
\end{tabular}

Note. Quantities are measured in chained (1992) dollars.

Source. U.S. Department of Commerce, Bureau of the Census.

continues to have a substantial positive balance of trade with respect to travel and passenger fares, business, professional, and technical services, royalties and license fees, and other private services. With respect to these last two categories, almost 60 percent of the $\$ 77$ billion of U.S. exports in 1996 represented transactions between "affiliated" enterprises-U.S. parent firms and their foreign subsidiaries; for royalties and license fees alone, the proportion was 80 percent. Much of the increase in royalties in recent years has been associated with affiliated companies in the computer technology and pharmaceuticals industries. In some respects, these exports can be viewed as an additional component of the already robust return on U.S. direct investment abroad.

\section{DEVELOPMENTS IN THE NONTRADE CURRENT ACCOUNT}

The two major components of the nontrade current account are net unilateral transfers and net investment income (table 1). Net unilateral transfers include government grant and pension payments as well as net private transfers to foreigners. Net investment income is the difference between the amount that U.S. residents earn on their assets abroad (receipts) and the amount that foreigners earn on their assets in the United States (payments). As mentioned earlier, the deficit on unilateral transfers increased $\$ 7$ billion because of disbursement delays for U.S. government grants caused by the budget impasse and government shutdown at the end of 1995. For 1996, the balance on investment income, which first went into deficit in 1994, was virtually unchanged, as an increase in the deficit on portfolio income was almost offset by the increase in the surplus on direct investment income (table 9).

\section{Net Portfolio Investment Income}

The first component of investment income, the balance on portfolio income, registered a deficit of $\$ 73$ billion in 1996, about $\$ 7$ billion higher than that recorded in 1995 (table 9). The balance on portfolio income has been in deficit since 1985, and its size has broadly mirrored the net portfolio investment

8. Transactions in services, 1993-96

Billions of dollars

\begin{tabular}{|c|c|c|c|c|c|}
\hline Item & 1993 & 1994 & 1995 & 1996 & $\begin{array}{l}\text { Change, } \\
1995 \text { to } 1996\end{array}$ \\
\hline Services transactions, net & 61 & 62 & 68 & 73 & 5 \\
\hline Military, net & 1 & 2 & 4 & 3 & -1 \\
\hline Sales ......... & 13 & 12 & 13 & 14 & 0 \\
\hline Expenditures & 12 & 10 & 10 & 11 & 1 \\
\hline Exports of private services ... & 172 & 183 & 196 & & 13 \\
\hline Travel and passenger fares & 74 & 75 & 80 & 84 & 4 \\
\hline Other transportation ....... & 24 & 26 & 28 & 29 & 1 \\
\hline 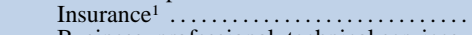 & 1 & 2 & 1 & 2 & 0 \\
\hline Business, professional, technical services & 13 & 16 & 16 & 17 & 1 \\
\hline Royalties and license fees $\ldots \ldots \ldots \ldots \ldots$ & 20 & 22 & 27 & 29 & 2 \\
\hline \multirow{2}{*}{$\begin{array}{l}\text { U.S. government receipts of } \\
\text { miscellaneous services }\end{array}$} & 40 & 42 & 44 & 48 & 4 \\
\hline & 1 & 1 & 1 & 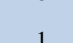 & 0 \\
\hline Imports of private services ... & & & 130 & 137 & 7 \\
\hline Travel and passenger fares & 52 & 57 & $\begin{array}{r}130 \\
60\end{array}$ & 63 & 3 \\
\hline Other transportation ........ & 26 & 28 & 29 & 29 & 0 \\
\hline Insurance $^{2} \ldots \ldots \ldots \ldots \ldots \ldots \ldots \ldots$ & 3 & $\begin{array}{r}20 \\
4\end{array}$ & 5 & 5 & 0 \\
\hline Business, professional, technical services & 4 & 4 & 5 & 5 & 0 \\
\hline Royalties and license fees $\ldots \ldots \ldots \ldots \ldots$ & 5 & 6 & 6 & 7 & 1 \\
\hline \multirow{3}{*}{$\begin{array}{l}\text { U.S. government payments for } \\
\text { miscellaneous services ... }\end{array}$} & 21 & 22 & 25 & 28 & 3 \\
\hline & & & & & \\
\hline & 2 & 3 & 3 & 3 & 0 \\
\hline
\end{tabular}


9. U.S. investment income, 1993-96

Billions of dollars

\begin{tabular}{|c|c|c|c|c|}
\hline Item & 1993 & 1994 & 1995 & 1996 \\
\hline Investment income, net & 10 & -4 & -8 & -8 \\
\hline Portfolio investment income, net & -46 & -52 & -66 & -73 \\
\hline Receipts ................ & $\begin{array}{r}-40 \\
58\end{array}$ & -73 & $\begin{array}{r}-00 \\
94\end{array}$ & $\begin{array}{r}-13 \\
98\end{array}$ \\
\hline Private ................ & 53 & 69 & 89 & 94 \\
\hline Government .... & 5 & $\begin{array}{r}09 \\
4\end{array}$ & 5 & $\begin{array}{r}94 \\
5\end{array}$ \\
\hline Payments ...... & 105 & 125 & 159 & 172 \\
\hline Private .......... & 63 & 78 & 98 & 100 \\
\hline Government .... & 42 & 47 & 61 & 71 \\
\hline Direct investment income, net . & 56 & 47 & 58 & 64 \\
\hline 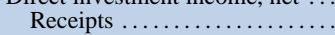 & 62 & 69 & 89 & 98 \\
\hline Payments ................. & 6 & 21 & 31 & 34 \\
\hline
\end{tabular}

Source. U.S. Department of Commerce, Bureau of Economic Analysis, U.S. international transactions accounts.

position-claims minus liabilities (chart 6). The net portfolio position deteriorated significantly last year, with the net liability position increasing $\$ 245$ billion, or 24 percent (chart 4). The 11 percent increase in net investment payments to foreigners was relatively modest by comparison, as a general decline in interest rates dampened the increase (chart 7).

\section{Net Direct Investment Income}

The second component of net investment income, the balance on net direct investment income, increased $\$ 6$ billion to a positive $\$ 64$ billion. Given that U.S. direct investment abroad and foreign direct investment in the United States increased by roughly equal amounts in 1996, the increase in net receipts was primarily the result of the higher rate of return earned on U.S. direct investment abroad (chart 8); a sec-

\section{Net portfolio investment: Position and income, 1972-96}

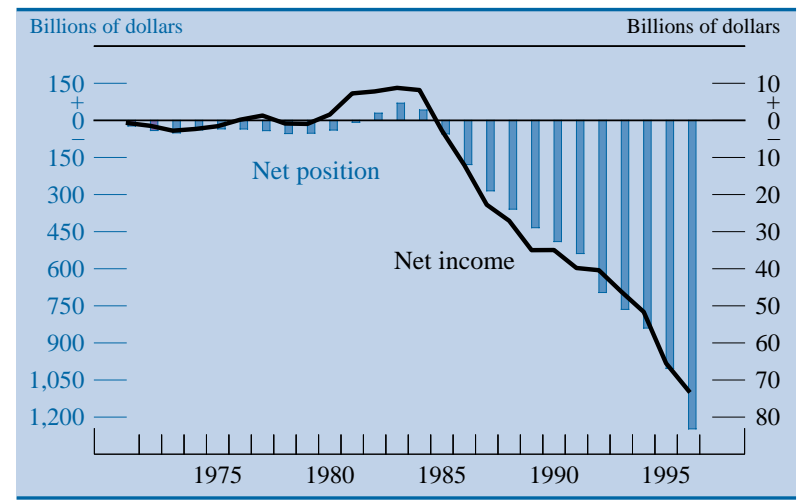

Note. The net position data are averages of the end-of-year net positions for the current and previous years. The year-end position for 1996 was constructed by adding the recorded portfolio investment flows during 1996 to the recorded year-end position for 1995 .

SourCE. U.S. Department of Commerce, Bureau of Economic Analysis; and the Federal Reserve Board.
7. Rates of return on U.S. portfolio investment, 1987-96

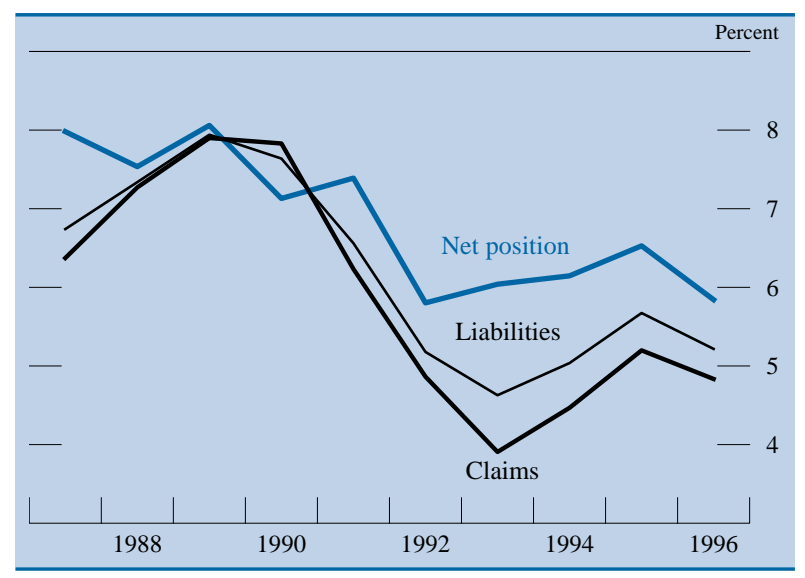

Note. The rates of return are annualized versions of quarterly rates calculated as follows: For claims (or liabilities), the numerator is total receipts (or payments) from the U.S. international transactions accounts, measured on a quarterly basis. The denominator is the average of end-of-quarter claims (or liabilities) for the current and previous quarters. To compute the numerator and denominator of the annualized rate of return, the numerators and denominators from the four quarterly rates of return are averaged.

The rate of return on the net position is calculated as the ratio of net investment income (annual receipts minus payments) to the annualized net position (annualized claims minus annualized liabilities).

Source. U.S. Department of Commerce, Bureau of Economic Analysis, U.S. international transactions accounts and U.S. international investment position; and the Federal Reserve Board.

ondary reason was the small reduction in the rate of return on foreign direct investment in the United States.

Various alternatives for measuring the rate of return on direct investment all lead to the same result for 1996 and for earlier years, as shown in table 10: Rates of return changed little from 1995 to 1996, and the rate of return on U.S. direct investment abroad continued to be more than double that on foreign direct investment in the United States. Given the importance of this differential, as noted previously, in mitigating the effect of the negative net investment position on the current account deficit, important and perennial questions are whether the differential will persist and whether it reflects biases in measurement rather than a true differential in underlying profitability. Researchers have investigated potential biases in both the numerator of the rate of return-direct investment receipts and payments from the U.S. international transactions accounts (table 9) - and its denominator - some measure of the value of the U.S. (foreign) ownership position in subsidiaries and branches abroad (in the United States).

Three measures of the value of direct investment have been constructed by the Bureau of Economic Analysis (BEA) and are used as alternative denominators in calculating the rates of return in table 10. BEA's original method of valuing direct investment, 
8. Direct investment abroad: Position and income, 1978-96

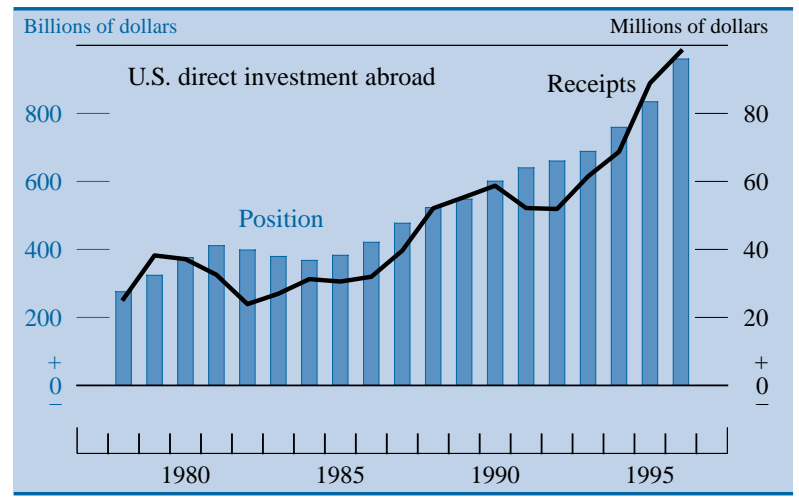

Note. The position data are averages using the current-cost measures as of year-end for the current and previous years. The year-end data for 1996 were constructed by adding the recorded direct investment flows during 1996 to the recorded year-end position for 1995 .

the historical cost method, values the assets of direct investors at the prices at which the assets were purchased. The other two measures attempt to correct for the biases inherent in the first. The value of direct investment at current cost adjusts the historical, accounting values for inventories and for plant and equipment to reflect current replacement values. The value of direct investment at market prices adjusts the ownership position using indexes of stock market prices. The estimated value of direct investment abroad is significantly higher when measured by either of these latter alternatives than it is when measured at historical costs; in 1995 the current cost measure was 23 percent higher and the market price measure 83 percent higher than the historical cost measure. For direct investment in the United States, the historical cost and the current cost measures differ by only 14 percent; however, because of the recent U.S. stock market increases, the market value measure is 82 percent greater than the historical cost measure.

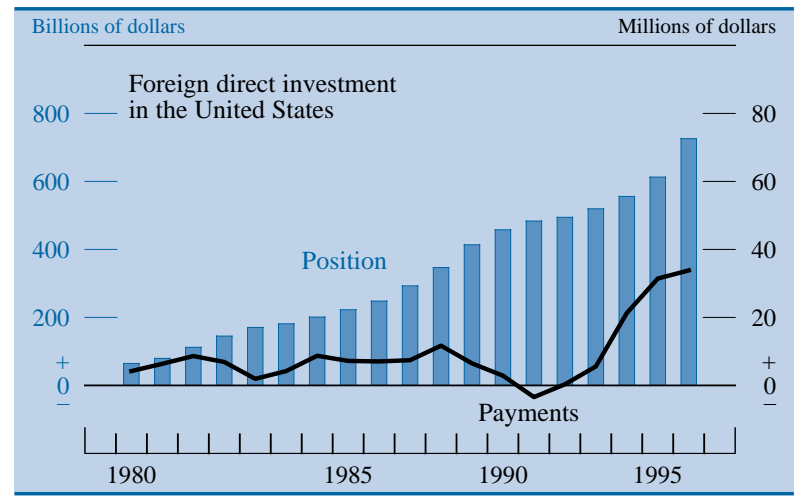

Source. U.S. Department of Commerce, Bureau of Economic Analysis; and the Federal Reserve Board.

For direct investment abroad, using the two alternative measures as denominators results in a significantly lower rate of return than when the historical cost measure is used; in 1996, for example, the rates of return for the current cost and market price measures differed from the historical cost measures by 2.3 and 5.7 percentage points respectively. In contrast, for direct investment in the United States, using either of the alternatives to the historical cost measure in the denominator reduces the rate of return in 1996 much less. This smaller reduction of the calculated rate of return is to be expected given the shorter length of time that the average foreign subsidiary in the United States has been in existence. In summary, the use of corrected measures for direct investment rather than the historical cost measure does in fact narrow the difference between the rates of return on direct investment abroad and in the United States; for 1996, a difference of 7.4 percentage points is reduced to 5.7 percentage points when the current cost measure is used and to 4.1 percentage points when

10. Rates of return on direct investment, 1989-96 Percent

\begin{tabular}{|c|c|c|c|c|c|c|c|c|}
\hline Measure used in calculating the rate of return ${ }^{1}$ & 1989 & 1990 & 1991 & 1992 & 1993 & 1994 & 1995 & 1996 \\
\hline \multicolumn{9}{|l|}{ U.S. investment abroad } \\
\hline Historical cost ........ & 15.2 & 14.5 & 11.6 & 10.7 & 11.5 & 11.6 & 13.3 & 13.0 \\
\hline Current $\operatorname{cost}(\ldots \ldots \ldots \ldots \ldots \ldots \ldots \ldots \ldots$ & 10.2 & 10.0 & 8.3 & 8.0 & 8.9 & 9.2 & 10.7 & 10.7 \\
\hline Market value $\ldots \ldots \ldots \ldots \ldots \ldots \ldots \ldots \ldots$ & 7.3 & 7.5 & 6.7 & 6.4 & 6.8 & 6.6 & 7.5 & 7.3 \\
\hline \multicolumn{9}{|l|}{ Foreign investment in the United States } \\
\hline Historical cost $\ldots \ldots \ldots \ldots \ldots \ldots \ldots \ldots \ldots \ldots \ldots \ldots \ldots$ & 1.9 & .8 & -.8 & .1 & 1.3 & 4.4 & 5.9 & 5.6 \\
\hline 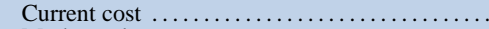 & 1.6 & .6 & -.7 & .1 & 1.1 & 3.8 & 5.2 & 5.0 \\
\hline Market value ... & 1.4 & .5 & -.6 & .0 & .8 & 2.8 & 3.5 & 3.2 \\
\hline \multicolumn{9}{|c|}{$\begin{array}{l}\text { 1. The rates of return are calculated as follows: The numerator is direct } \\
\text { investment receipts or payments, from the U.S. international transactions } \\
\text { accounts. The denominator is the average of year-end figures for the current and } \\
\text { previous year for the particular measure of the value of direct investment shown. } \\
\text { Each denominator for } 1996 \text { is constructed by adding the recorded direct invest- } \\
\text { ment flows during } 1996 \text { to the recorded year-end positions for } 1995 \text {. }\end{array}$} \\
\hline
\end{tabular}


the market value measure is used. However, the adjusted rates of return for U.S. direct investment abroad in 1996 remain almost twice those for foreign direct investment in the United States.

As for the numerator, a number of potential sources of either bias or systematic difference have been identified by researchers. Because of problems in the comparability of the rate-of-return data, however, there now exists only indirect evidence on the size and importance of these factors. In particular, a recent study by Grubert, Goodspeed, and Swenson, has made significant progress in providing such indirect evidence by using corporate tax return data to analyze differences in rates of return between foreign subsidiaries in the United States and domestically owned firms in the United States. ${ }^{1}$ Because the study used two sets of firms in the United States, it does not provide a direct comparison of the rate of return for these firms with the rate of return on foreign investment abroad. It does explain about 50 percent of the difference between the rates of return for the two sets of firms by the following factors: (1) the revaluation of the assets of foreign subsidiaries in the United States after they are acquired, which, because of higher depreciation flows, lowered their rate of return; (2) the relative age of the subsidiary, with more mature firms earning higher rates of return; (3) the effects of exchange rate changes on the prices of imported inputs; (4) the amount of repatriated dividends and royalties from foreign operations controlled by the domestically owned U.S. firms, which raised the rate of return disproportionately for these firms; and (5) the effects of transfer pricing, by which firms shift reported profits to jurisdictions that have lower tax rates.

The first two of these factors suggest that, over time, the rates of return on foreign direct investment in the United States will rise-narrowing, therefore, the difference in the rates of return seen in table 10. The third and fourth factors shed no light on longterm differences in the rates of return. Finally, the effects of transfer pricing may distort the rates of return on direct investment in the United States and abroad, as profits are shifted to low-tax jurisdictions; how this factor will affect the difference in the rate of return is unknown. However, while the particular

1. Harry Grubert, Timothy Goodspeed, and Deborah Swenson, "Explaining the Low Taxable Income of Foreign-Controlled Companies in the United States," in Alberto Giovannini, R. Glenn Hubbard, and Joel Slemrod, eds., Studies in International Taxation (University of Chicago Press, 1993). See also the update of this study: Harry Grubert, Another Look at the Low Taxable Income of ForeignControlled Companies in the United States (U.S. Department of the Treasury, 1996). distortion caused by transfer pricing may affect direct investment receipts and payments in the balance of payments to an unknown degree, it will not affect the current account balance: Lower (or higher) direct investment profits caused by transfer pricing will be offset one-to-one by higher (or lower) import payments.

\section{CAPITAL ACCOUNT TRANSACTIONS}

Record inflows of official capital and large net foreign purchases of U.S. Treasury and corporate bonds in 1996 more than offset both the $\$ 165$ billion deficit on the U.S. current account and substantial net capital outflows through banks and for the purchase of foreign securities (table 11). For the first year since 1992, the statistical discrepancy turned negative and ended the year at $\$ 53$ billion.

Foreign official assets held in the United States increased by a record $\$ 123$ billion in 1996, surpassing the previous record set just the year before. Part of the increase was associated with exchange market intervention and the accumulation of interest receipts by the Group of Ten countries, and another small part reflected the effect of favorable oil price developments on the holdings of OPEC countries. However, more than half the increase was in official holdings of other countries.

Private foreign net purchases of Treasury securities and corporate bonds exceeded the already high purchases in 1995. Net purchases of Treasury securities, at $\$ 154$ billion, reached a new high; most of the transactions were with financial institutions in the United Kingdom, so the nationality of the ultimate investors is unclear. Net purchases of Treasury securities by financial centers in the Caribbean were large and volatile, but the net of purchases and sales in 1996 was only about two-thirds the size recorded in 1995.

Private foreign net purchases of U.S. corporate and U.S. government agency bonds were also large for the year. However, private foreign net purchases of U.S. corporate stocks continued to be very small. In contrast, U.S. investors remained interested in both foreign stocks and bonds and purchased a net of $\$ 58$ billion and $\$ 45$ billion respectively.

Large direct investment capital flows occurred in both directions. Foreign direct investment in the United States surged to a record high $\$ 84$ billion, reflecting a pickup in foreign acquisitions of U.S. firms. U.S. direct investment flows abroad were even stronger, at $\$ 88$ billion, although off slightly from the record rate of 1995 . 
11. Composition of U.S. capital flows, 1992-96

Billions of dollars

\begin{tabular}{|c|c|c|c|c|c|c|}
\hline Item & 1992 & 1993 & 1994 & 1995 & 1996 & $\begin{array}{c}\text { Change, } \\
1995 \text { to } 1996\end{array}$ \\
\hline Current account balance & -63 & -100 & -148 & -148 & -165 & -17 \\
\hline Official capital, net $\ldots \ldots \ldots \ldots \ldots \ldots \ldots$ & 43 & 70 & 45 & 100 & 129 & 29 \\
\hline Foreign official assets in the United States ....... & 41 & 72 & 40 & 110 & 123 & 13 \\
\hline U.S. official reserve assets . ................ & 4 & -1 & 5 & -10 & 7 & 17 \\
\hline Other U.S. government assets $\ldots \ldots \ldots \ldots \ldots \ldots$ & -2 & 0 & 0 & 0 & -1 & -1 \\
\hline Private capital, net $\ldots \ldots \ldots \ldots \ldots \ldots \ldots \ldots \ldots$ & 45 & -14 & 89 & 17 & 89 & 72 \\
\hline Net inflows reported by U.S. banking offices ... & 36 & 51 & 104 & -44 & -90 & -46 \\
\hline Securities transactions, net $\ldots \ldots \ldots \ldots \ldots \ldots$ & 14 & -42 & 31 & 95 & 180 & 85 \\
\hline Private foreign net purchases of U.S. securities & 64 & 104 & 91 & 193 & 285 & 92 \\
\hline Treasury securities $\ldots \ldots \ldots \ldots \ldots \ldots \ldots \ldots$ & 37 & 24 & 34 & 99 & 154 & 55 \\
\hline Corporate and other bonds ${ }^{1} \ldots \ldots \ldots \ldots$. & 31 & 61 & 54 & 81 & 119 & 38 \\
\hline Corporate stocks $\ldots \ldots \ldots \ldots \ldots \ldots$ & -4 & 19 & 3 & 13 & 12 & -1 \\
\hline U.S. net purchases of foreign securities ...... & -49 & -146 & -60 & -99 & -105 & -6 \\
\hline 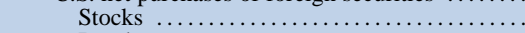 & -32 & -63 & -48 & -50 & -58 & -8 \\
\hline Bonds $\ldots \ldots \ldots \ldots \ldots \ldots$ & -16 & -80 & -9 & -48 & -45 & 3 \\
\hline Direct investment, net $\ldots \ldots \ldots \ldots \ldots \ldots \ldots \ldots$ & -21 & -33 & -5 & -35 & -4 & 31 \\
\hline Foreign direct investment in the United States . & 18 & 43 & 50 & 60 & 84 & 24 \\
\hline U.S. direct investment abroad ${ }^{1} \ldots \ldots \ldots \ldots$ & -39 & -76 & -55 & -96 & -88 & 7 \\
\hline Other $\ldots \ldots \ldots \ldots \ldots \ldots \ldots \ldots$ & 14 & 12 & -41 & 0 & 3 & 3 \\
\hline Statistical discrepancy & -23 & 44 & 14 & 32 & -53 & -85 \\
\hline
\end{tabular}

1. For 1992, transactions with finance affiliates in the Netherlands Antilles are excluded from direct investment outflows and included in foreign purchases of U.S. securities. This adjustment was discontinued in 1993 on the assumption that by then virtually all the Eurobonds issued by Netherlands Antilles had come

Source. U.S. Department of Co international transactions accounts.

\section{PROSPECTS FOR 1997}

Given the prospects for continued moderate growth abroad and the strength of foreign demand for U.S. computer products and aircraft, U.S. exports of goods and services, in both nominal and real terms, should continue to expand in 1997. However, the tendency for U.S. imports to be more sensitive than U.S.

exports to economic growth, along with the recent appreciation of the U.S. dollar, suggests that the current account deficit in 1997 will be larger than in 1996. Whether the deficit actually increases in 1997 will also depend on many other factors, including changes in the price of oil and in the rates of return that will be earned on existing U.S. claims and liabilities. 